\title{
Investigation of MDM2 Oncogene Copy Number Alterations in Cases of Chronic Lymphocytic Leukemia
}

\author{
Kronik Lenfositik Lösemi Olgularında MDM2 Onkogen Kopya Sayısı Değişiminin \\ Araştıııması
}

\author{
(D) Şule Darbaş¹, (D) Çiğdem Aydın², (D) Ozan Salim³ , (D) Sibel Berker Karaüzüm¹ \\ ${ }_{1}^{1}$ Akdeniz University Faculty of Medicine, Department of Medical Biology and Genetics, Antalya, Turkey \\ ${ }^{2}$ Mehmet Akif Ersoy University Bucak School of Health, Department of Nursing, Burdur, Turkey \\ ${ }^{3}$ Akdeniz University Faculty of Medicine, Department of Hematology, Antalya, Turkey
}

\section{To the Editor,}

Chronic lymphocytic leukemia (CLL) is a disease characterized by deposition of malignant monoclonal lymphocytes. Chromosomal abnormalities have been determined in 30\%-50\% of patients with CLL [1]. The most common chromosomal abnormalities are $13 q 14$ deletion (51\%), 11q22.3 deletion (17\%-20\%), trisomy 12 (15\%), 17p13 deletion (7\%), $6 q 23$ deletion $(7 \%)$, and $t(14 ; 19)$ translocation (1\%-2\%) $[2,3]$.

In CLL patients, overexpression of the MDM2 gene was shown in earlier studies at protein and RNA levels $[4,5,6]$, and it was aimed to be shown at the DNA level for the first time in this study.

MDM2 gene amplification was investigated by the fluorescence in situ hybridization (FISH) method in 40 patients with CLL and 20 patients with $\mathrm{Ph}+$ chronic myeloid leukemia as a control group. Informed consent was received. The modified Rai staging system was used for staging our patients. Conventional cytogenetic analysis and FISH analysis using CLL-specific FISH probes for 17p13.1 (TP53), 13q14 (RB), 6q22-q23 (MYB), 11q22.3 (ATM), and chromosome 12 centromere were applied for all patients. The cytogenetic analysis revealed abnormal karyotypes in 3 of 40 patients. 47,XX,inv(9)(p11q13),del(13)(q14),+21[2],46,XY,del (7) (q31),dup(12)(q21q21)[8], and 46,XY,del(20)(q12)[6] karyotypes were observed in these patients. MDM2 gene amplification could not be detected in either the patient or the control group. FISH analysis results were as follows in CLL cases: deletion of $17 p 13.1$ in 16 cases (40\%), 13q14 deletion in 13 cases (32.5\%), trisomy 12 in 12 cases (30\%), 11q22.3 deletion in 6 cases (15\%), and $6 q 23$ deletion in 1 case $(2.5 \%)$. Frequencies of molecular cytogenetic findings are presented in Figure $1 \mathrm{~A}$. Compared to the literature, where the frequency of deletion of $17 p 13.1$ in early-stage CLL was reported between $7 \%$ and $10 \%[7,8]$, the higher rate observed in $75 \%$ of our CLL patients might be due to differences in the methods and probes used, variability of laboratory cut-off values, or the limited number of cases in this study. The clinical implication of having 17p13.1 deletions in
CLL cases might be more dependent on the extent of $17 p 13.1$ deletion than the stage of the disease [9]. In the present study, only 4 patients had $17 p 13.1$ deletion in $>20$ cells. Two of them died because of progressive disease and the other two were lost to follow-up. If evaluated from this perspective, the high level of 17p13.1 deletion was observed in 10\% of our cases. It has been observed that patients with 17p13.1 and 11q2.3 deletion have a poor prognosis, and patients with isolated $13 q 14$ deletion were found to have slower progression and longer survival time
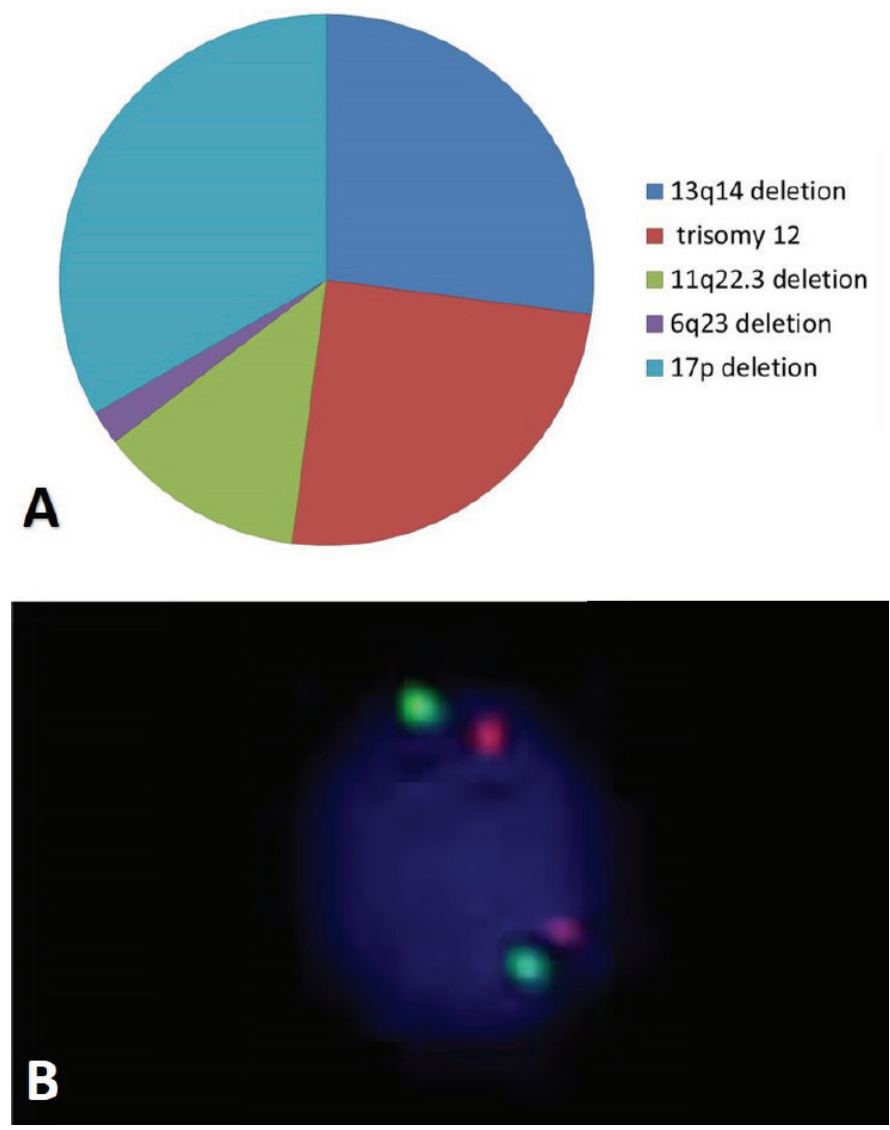

Figure 1. A) Chromosomal abnormalities detected by routine fluorescence in situ hybridization (FISH) analysis of 40 chronic lymphocytic leukemia cases. B) Signal patterns in interphase nuclei of normal FISH results for the MDM2 gene. 
[2]. We observed that early-stage patients with isolated $13 q 14$ deletion showed slower progression and these patients did not have treatment indications.

MDM2 has pivotal roles in the regulation and stabilization of p53 [10]. In our study, amplification of the MDM2 gene was not determined in CLL patients, but 30 (75\%) of 40 cases were clinically diagnosed as an early stage by the FISH method (Figure 1B). We thought that the absence of MDM2 gene amplification in our patients might be related to the early stage of the disease. On the other hand, the reason for being unable to observe amplification of the MDM2 gene in $10(25 \%)$ of 40 patients at advanced stages might be the presence of other abnormalities such as trisomy 12 or deletions of $17 p 13.1$, $11 q 22.3$, and $6 q 23$. We also suggest that reevaluation of MDM2 gene amplification in patients having a relapse in the future is important for demonstrating the MDM2-CLL relationship. In previous studies, MDM2 overexpression was examined at mRNA and protein levels $[4,5,6]$, but amplification of the MDM2 gene at DNA level in CLL patients has been examined for the first time in our study.

Keywords: MDM2, Chronic lymphocytic leukemia, Fluorescence in situ hybridization, P53

Anahtar Sözcükler: MDM2, Kronik lenfositik lösemi, Floresan in situ hibridizasyon, P53

Informed Consent: It was received.

Conflict of Interest: The authors of this paper have no conflicts of interest including specific financial interests, relationships, and/or affiliations relevant to the subject matter or materials included.

\section{References}

1. Glassman $A B$, Hayes $K J$. The value of fluorescence in situ hybridization in the diagnosis and prognosis of chronic lymphocytic leukemia. Cancer Genet Cytogenet 2005;158:88-91.

2. Döhner $H$, Stilgenbauer $S$, Benner $A$, Leupolt $E$, Kröber $A$, Bullinger $L$, Döhner K, Bentz M, Lichter P. Genomic aberrations and survival in chronic lymphocytic leukemia. N Engl J Med 2000;343:1910-1916.

3. Mayr C, Speicher MR, Kofler DM, Buhmann R, Strehl J, Busch R, Hallek $\mathrm{M}$, Wendtner CM. Chromosomal translocations are associated with poor prognosis in chronic lymphocytic leukemia. Blood 2006;107:742-751.

4. Bueso-Ramos CE, Yang $Y$, deleon $E$, McCown $P$, Stass SA, Albitar M. The human MDM-2 oncogene is overexpressed in leukemias. Blood 1993;82:2617-2623.

5. Haidar MA, El-Hajj H, Bueso-Ramos CE, Manshouri T, Glassman A, Keating MJ, Maher A. Expression profile of MDM-2 proteins in chronic lymphocytic leukemia and their clinical relevance. Am J Hematol 1997;54:189-195.

6. Winkler D, Schneider C, Kröber A, Pasqualucci L, Lichter P, Döhner H, Stilgenbauer $S$. Protein expression analysis of chromosome 12 candidate genes in chronic lymphocytic leukemia (CLL). Leukemia 2005;19:1211-1215.

7. Yu L, Kim HT, Kasar S, Benien P, Du W, Hoang K, Aw A, Tesar B, Improgo R, Fernandes S, Radhakrishnan S, Klitgaard J, Lee C, Getz G, Setlur SR, Brown JR. Survival of del17p CLL depends on genomic complexity and somatic mutation. Clin Cancer Res 2017;23:735-745.

8. Hallek M. Chronic lymphocytic leukemia: 2017 update on diagnosis, risk stratification, and treatment. Am J Hematol 2017;92:946-965.

9. Tam CS, Shanafelt TD, Wierda WG, Abruzzo LV, Van Dyke DL, O'Brien S Ferrajoli A, Lerner SA, Lynn A, Kay NE, Keating MJ. De novo deletion 17p13.1 chronic lymphocytic leukemia shows significant clinical heterogeneity: the M. D. Anderson and Mayo Clinic experience. Blood 2009;114:957-964.

10. Pei D, Zhang Y, Zheng J. Regulation of p53: a collaboration between Mdm2 and Mdmx. Oncotarget 2012;3:228-235.

๑Copyright 2019 by Turkish Society of Hematology

Turkish Journal of Hematology, Published by Galenos Publishing House

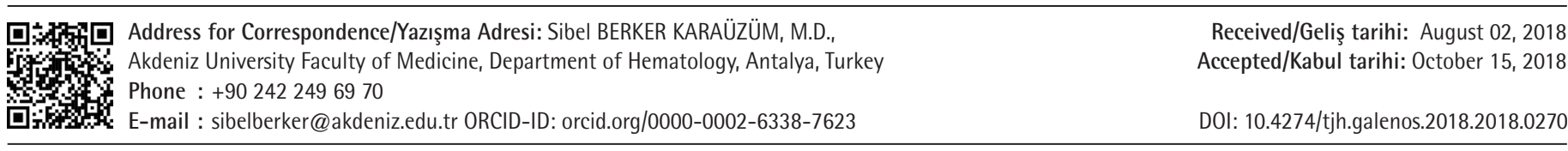

